\title{
Students' Computer Skills and Students' Achievement in Senior Secondary School Biology in Ogun State, Nigeria
}

\author{
Kuburat O. Towolawi \\ Bells University of Technology, Ota \\ PMB 1015, Ogun-State, Nigeria
}

\author{
Adams O. U. Onuka \\ Professor \\ Institute of Education \\ University of Ibadan, Ibadan, Nigeria
}

\begin{abstract}
Biology is a study of life and it is essential that students studying any science related course have an understanding of the subject, however, students' achievement in Senior Secondary Certificate Examination in Biology in Nigeria generally and in Ogun State in particular has been seemly poor and declining [5], [29], [21]. This trend has been partially attributed to students' low computer skills and utilisation of ICT facilities. Among others; thus, raising concern about that portent danger for the possibility of realizing the objectives of science education. Some previous studies have largely focused on proprietors, school, parents and students' related factors. The study adopted ex-post facto design of the correlational type. Multistage sampling technique was employed to select the participants. A total of 2548 SSS II science students participated. Computer Skills Assessment Questionnaires (CSAQ) was validated using Pearson Product Moment Correlation (PPMC) with 0.91 reliability coefficient and Achievement Tests Biology with reliability coefficient of were used to collect the data for the study. The ensuing data from the field exercise were analysed using Pearson product moment correlation and multiple regression statistics at 0.05 level of significance to test the hypotheses. The results showed that there was significant difference in students' achievement in Biology based on school type. Also, students computer skills correlate with achievement in Biology in both public and private secondary schools in Ogun state. The study, therefore, recommended that examination bodies should include computer skills acquisition in Senior Secondary Certificate Examination syllabi and the testing of computer skills in addition to covering the cognitive domain of learning in Biology.
\end{abstract}

\section{General Terms}

Computer Skills assessment, Secondary School Biology, Achievements

\section{Keywords}

Secondary School Students, Computer skills, Academic Achievement, Biology Achievement, Ogun State, Nigeria

\section{INTRODUCTION}

The study of life extends from the microscopic scale of the cell that makes up organism to the global scale of the entire living planet. Through the study of Biology, students are able to employ certain aspects of science in scientific investigations. Students are able to explore the diversity of life; the inter-relationship between organisms and the environment. In addition, students also develop the understanding and knowledge of the unit of life (the cell), whose structures and processes are shared by all living organisms. In so doing, students' are able to gain insight into the uniqueness, function and role of organisms, including themselves. Through the study of Biology, students also become aware of the uses of other living organisms and their products to enhance human health and the human environment in order to make informed evaluation about contemporary biological issues [21].

\section{BIOLOGY AS A SCIENCE SUBJECT 2.1 What is Biology}

Biology as a science subject is accorded an important position in the Nigeria National Policy of Education document and it is the most popular science subject in the senior secondary school system in Nigeria. It is a subject which covets high enrolment figure annually relative to Chemistry and Physics, the other science subjects [10]. Accordingly, Biology in the senior secondary school curriculum is meant to prepare students for learning experiences through which they develop the necessary biological knowledge and understanding. They will also develop scientific process skills, values and attitudes for their personal development. All these will inculcate into them the ability to cope with the dynamics of our everchanging society. They could then be equipped to contribute their quota towards a scientific and technological world as clearly shown in the various syllabi of examining bodies at the secondary education level in Nigeria [17], [29]. [36] corroborated the above by stating that Biology occupies a unique position in the school curriculum and this makes it central to many science related courses. Hence, no student intending to study science related disciplines can do without Biology and this position has drawn the attention of researchers and curriculum planners towards Biology as a subject in the school curriculum.

\subsection{Trend of Performance of Students in Biology Examinations}

In spite of the importance and popularity of Biology among Nigerian students, performance at senior secondary school level have been reported to be poor according to [5], [21] and [28]. This trend was reported to be due to the daily challenges confronting students in Nigeria secondary schools. These challenges are the challenges of coping with their studies under serious emotional and economical strains, long walk to school, poor school environment and receiving instructions from unmotivated teachers. Beside the aforementioned, is the attitude of parents to monitor the academic progress of their ward as a result of 
economic incapacitation. Consequently, students' academic achievement in West African Examinations Council (WAEC), and the National Examinations Council (NECO), Secondary School Certificate Examinations (SSCE) has been reported to be generally poor and declining yearly especially in the sciences [22], [30] and [18].

Table 1 shows a ten-year poor and parlous trend of students' performance in biology at Senior School Certificate Examination (SSCE) from 2004-2014. Table 1: Percentage Distribution of Students' Performance in May/June Senior School Certificate (SSCE) Biology $2004-2014$

\begin{tabular}{|l|l|l|l|l|}
\hline Year & $\begin{array}{l}\text { Total } \\
\text { Entry }\end{array}$ & Total Sat & $\begin{array}{l}\text { Credit } \\
\text { passes } \\
(\mathbf{1 - 6})\end{array}$ & $\begin{array}{l}\text { Percentage } \\
\text { Passes }\end{array}$ \\
\hline 2004 & $1,005,553$ & $1,027,938$ & 253,487 & 24.69 \\
\hline 2005 & $1.080,162$ & $1,072,607$ & 375,850 & 35.04 \\
\hline 2006 & $1,170,522$ & $1,152,045$ & 559,854 & 48.60 \\
\hline 2007 & $1,270,137$ & $1,238,163$ & 413,211 & 33.37 \\
\hline 2008 & $1,292,910$ & $1,259,964$ & 427,644 & 33.94 \\
\hline 2009 & $1,372,567$ & $1,340,206$ & 453,928 & 33.87 \\
\hline 2010 & $1,331,381$ & $1,300,418$ & 427,644 & 33.90 \\
\hline 2011 & $1,540,141$ & $1,505,199$ & 579,432 & 38.50 \\
\hline 2012 & $1,695,878$ & $1,672,224$ & 649,156 & 38.82 \\
\hline 2013 & $1,440,163$ & $1,282,119$ & 478,112 & 34.59 \\
\hline 2014 & $1,498,831$ & $\begin{array}{l}1, \\
449,101\end{array}$ & 542,249 & 37.42 \\
\hline
\end{tabular}

Source: West African Examination Council Examiners Report

From table 1, it is evident that between the years 20042014 , the population of students who passed biology at credit level in WASSCE was below 35\%, except in 2006, 2011 and 2012 when the percentage credit passes rose to $48.6 \%, 38.5 \%, 38.8 \%$ and $37.42 \%$ respectively. This means that over the years, the percentage of students who qualified to pursue science based courses in the university is below $35 \%$. This is quite ridiculous for a developing nation that is orchestrating scientific advancement for its national development. Therefore, if this poor achievement in biology and other science subjects is not given prompt and proper attention, it will definitely affect the nation's level of scientific and technological advancement. It could also equally affect the Nigeria vision of a scientifically oriented society; the realization of the vision 2020 and the educational aspiration of achieving the ratio 40:60 in art to science

For Nigeria, a developing country that needs science and technology for its development, the poor achievement of students in the sciences and worse still, the very insignificant numbers of students who pass at credit level and thereafter choose science as a course of study after secondary education is worrisome [5], [21] and [28]. In recent times, literature has also shown that academic achievement could be determined by such variables as: family, school, society, and motivation [2]. Thus, students' academic achievement cannot be completely accounted for by only one or two variables but a number of them. Summarily, students academic achievement depends on a number of variables and such performance could be enhanced through identification and manipulation of each of the identified variables [14].

\subsubsection{Reasons adduced for the Poor Trend of Performance in Biology}

The poor trend in students' performance in the sciences including Biology have been traced and attested to by literature to include the medium through which knowledge is imparted to learners. [8] explained, that, Biology as a subject has some identified major problem areas that cause ineffective learning. These problems include concept misunderstanding, basic content ambiguity and unclear biological terminologies among others. All of which are due to ineffective teaching and teachers' inadaptability at using quick sketches to explain certain content and or in drawing diagram. Another factor is lack of knowledgebase to link scientific content with day to day life examples. This trend is serious and worrisome to stakeholders (teachers, parents and researchers) especially when good academic achievement is a prerequisite for admission at all levels of education or employment. [5], [28] and [21].

It is not out of place to state that a lot of other factors also have possible effects on the academic achievement of students. [24] revealed that poor achievement of students can be attributed to factors such as school: the dearth of qualified and dedicated teaching staff, inadequate teaching and learning facilities in school such as books, laboratory, furniture etc; high student /teacher ratio, poor preparation, non-coverage of examination syllabus; general indiscipline and high rate of examination malpractice; teacher: their poor knowledge of subject content, lack of commitment, poor attitude, low level resourcefulness, strike action); parent factors their non challant attitude towards educational growth of ward, low socio-economic status, poor financial commitment, parental compromise; student: their poor reading habit, truancy, inadequate preparation for examination, over reliance on external assistance during examination among others and government: insufficient funding, monitoring and supervision of schools, lack of commitment, on the job training programmes for teachers and lack recruitment of qualified teachers etcetera .The findings from Okpala corroborated the study of [21] which posit that the poor performance of students in science subjects has been attributed to poor teaching methods in the form of excessive talking, copying of notes and rote learning of text book materials adopted by teachers.

\section{CONCEPT OF COMPUTER SKILLS 3.1 What is Computer Skills?}

Computer Skills in a lay man's language is the ability to use a computer. The [34] an online dictionary, defined computer skills as the level of expertise and familiarity someone has with computer generally and the ability to use computer applications rather than the program. Computer skills is grouped into four namely: Knowledge and skills in operating a computer using a library of programs; Knowledge of various ethical and social issues relating to computer use; a functional level of knowledge for the use of computers as an aid to problem solving and another significant part is the ability to communicate or gain access to information by using the computer as a tool.

Thus, computer skills in this study fall into the ability of students to communicate or gain access to information by using the computer as a tool. That is the basic ability which students' possess in order to be able to effectively use the computer and related technologies for basic 
activities of learning. [33], further defined computer skills as the ease of use and ability to operate a computer as a problem-solving tool. They also proposed that students should have basic computer skills in word processing, software, spread sheets, file management, graphics, and email. However, the knowledge of computer has surpassed the knowledge of science as a critical filter for employment opportunities and career pursuit. Meanwhile, it could be an assumption that secondary school students possess enough computer skills to enable them access the internet while registering for their certification and placement examinations like Secondary School Certificate Examination (SSCE) conducted by the West African Examination Council (WAEC) and the National Examinations Council (NECO)), and University Matriculation Examinations (UME) and Polytechnic and College of Education Entrance Examinations (PCE) conducted by the Joint Admissions and Matriculations Board (JAMB) respectively.

The aforementioned precludes any attempt at examining how much knowledge or understanding of the computer literacy skill that students possess. However, as soon as secondary school student graduate and get admitted into one of the institutions of higher learning, particularly the universities, they are further required to fill different forms online such as bio data, course registration, accommodation registration and even checking tutorial group and results online. Hence, in order to bring insight into the student computer skills and achievement in Biology, it is required that an evaluative measure be put in place for students computer literacy skills. This from educator's perspective could act as supplementary assessment tool.

\subsection{Computerisation project attempts in Secondary Schools in Nigeria}

In attempts to put evaluative measures in place for students computer literacy skills, few state government in the south western part of Nigeria envisaged the situation and took positive computerisation project step in their states. Lagos State government of Nigeria according to [1] reportedly took the first step through its Ministry of Science and Technology to launch a program tagged global computerization project. This project encompassed the establishment of local and wide area (LAN/WAN) networking of the Lagos State machinery, as well as the attendant introduction of ICT into her secondary schools. It also made provision for forty secondary schools, by distributing twenty microcomputers each to all the selected forty government owned secondary schools, with connection to the internet and the development of the curriculum for ICT in Schools project. The government also embarked on re-training of all its secondary school teachers as train-the -trainers to implement the ICT curriculum. In addition digital villages where trained teachers and students may go for drill and practice after school or during weekends were established.

In another attempt to computerize and imitate its counterpart State, the above verdict for the use of computers in secondary education also spurred the government of Osun-State, Nigeria into the idea of launching the Opon-Imo (Tablet of Knowledge) in the State capital Ilesa. The Opon-Imo a stand-alone e-learning tablet was designed to provide senior secondary students with learning materials that are required to prepare the students for school-leaving examinations. Each tablet was designed by Harvard University for Osun State's exclusive use. The tablet however, resembled an $i P a d$ and is preloaded with more than 50 textbooks, lesson notes, virtual classroom and other learning resources for secondary school pupils. It also features dictionary, bible, books on the history of the Yoruba and Opon Ifa (divination corpuses). The above innovation is a great leap forward for the state's effort at e-learning and to develop their computer skills. These attempts was also expected to put to an end to the dismal record of students' performance in public examinations.

It is in the light of the foregoing that, this study investigated student computer skills as determinants of achievement in Biology among senior secondary students in Ogun State, Nigeria. Thus, the need for computer skills development in the secondary school system of Ogun State becomes apparently imperative and the obvious need to change instructional strategies in order to improve academic achievements in Biology informs this research undertaken. In view of the foregoing, this study seeks to determine the extent to which student computer skills determine achievement in senior secondary school Biology in Ogun State, Nigeria.

\subsection{Research Questions}

Based on the problem identified from literature, the study was guided by the following research questions:

- Will students computer skills determine secondary school students achievement in Biology based on school type?

- Will there be difference in the secondary school students achievement in Biology based on school type

\subsection{Research Hypotheses}

Based on the Research Questions, the following hypotheses were tested

$\mathrm{H}_{1}$ : There is no significant relationship between secondary school students computer skills and their achievement in Biology in Ogun State?

$\mathrm{HO}_{2}$ : There is no significant difference in the secondary school students achievement in Biology

Based on school type?

\subsection{Methodology}

The study adopted expos-facto design of the correlational type because all variables of interest have occurred as such there was no manipulations. Multistage sampling procedure was used as follows: the schools were clustered by ownership. Purposive sampling technique was used to select 16 public and 16 private schools (only schools with over 10 computer sets - provided not more than 5 students use one at a time were included). A total of 2548 SSS II science students participated. Computer Skills Assessment Questionnaires (CSAQ) was validated using Pearson Product Moment Correlation (PPMC) with 0.91 reliability coefficient and Achievement Tests Biology: were used to collect the data for the study. The ensuing data from the field exercise were analysed using Pearson product moment correlation and multiple regression statistics at 0.05 level of significance.

\section{RESULTS}

4.1 Hypothesis 1: There is no significant relationship between secondary school students computer skills and their achievement in Biology in Ogun State? 
Table 2 presents the findings

Table 2: Summary of the Relationship between secondary school Students' Computer Skills and their achievement in Biology in Ogun State

Table 2: Correlation analysis showing the Relationship between students Computer Skills and achievement of secondary school students in Ogun State, Nigeria

\begin{tabular}{|l|l|l|l|l|l|l|}
\hline Variable & N & Mean & Std. D & R & P & Remark \\
\hline Computer & & 16.2794 & 4.8839 & & & \\
Skills & 2548 & & & $0.78 * *$ &. & Sig. \\
Achievement & & & & & 0 & \\
in Biology & & 7.8187 & 3.5773 & & 0 & \\
\hline
\end{tabular}

$*$ Sig= Significant

4.2 Hypothesis 2: There is no significant difference in the secondary school students achievement in Biology based on school type

Table 3 presents the findings?

Table 3: Comparison of secondary school students achievement in Biology based on school type

\begin{tabular}{|l|l|l|l|l|l|l|l|}
\hline $\begin{array}{l}\text { Academic } \\
\text { Achievement }\end{array}$ & N & Mean & Std. Dev. & Cal. t & DF & P & Comment \\
\hline $\begin{array}{l}\text { Private } \\
\text { School }\end{array}$ & 786 & 16.4359 & 5.6069 & 4.608 & 2546 & .00 & $*$ Sig \\
$\begin{array}{l}\text { Public } \\
\text { school }\end{array}$ & 1762 & 15.9288. & 4.5173 & & & & \\
\hline
\end{tabular}

\subsection{Discussion}

Table 2 shows the relationship between computer skills and achievement in Biology. The study revealed that computer skills has positive significant relationship with academic achievement of secondary school Biology students in Ogun State $(\mathrm{r}=0.78, \mathrm{~N}=2548, \mathrm{P}(0.00)<.05)$ which suggest that the higher the computer skill level of SSS 11 Biology students, the better they would perform in their achievement. Thus, it can be deduced from the result on the table that for every level of students' computer skills, there will be a corresponding improvement in achievement of secondary school students in Ogun state. The inference to be drawn from this is that, the computer skills of SSS Biology students in Ogun State would determine achievement in Biology

Information on Table 2 indicated: $\mathrm{r}=0.78, \mathrm{~N}=2548$, $\mathrm{P}=.00<.05\}$ p-value is. 000 , which means it is significant. Thus, there is positive significant relationship between students computer skills and their achievement This is evidenced from the mean scores of 282.0272 of public students and those of private schools of 281.3397. Hence, there is significant relationship between student's computer skills and academic achievement among public and private secondary schools in Ogun state. This finding is in tandem with the findings of [5], [26] and [19] that students' academic achievement is a function some other variable that could influence

Table 3 indicates that the calculated t-value is 4.60 with $\mathrm{p}$ value .000 , it means there is positive significant difference. Thus, there is significant difference in the achievement of secondary school biology students based on school type. This is evidenced from the difference in the mean scores of 16.4359 of public students and those of private schools of
15.9288, However, public school biology students have higher mean score than what obtains in the private schools. The higher mean is in favor of biology students in the public schools. The finding of this study, contradicted the finding of [25], that, students from both private and public schools have equal intellectual capabilities. In the same vein, the finding does contradict the result of the work of [37], which showed that school type had no significant influence on students' academic achievement. The findings of this study however agree with that of [26] who also discovered similar result when he studied academic achievement across school types (conventional public schools and Hawaiian Language and Culture- based (HLCB) schools) in Hawai'i. Again, the similarity in the report on achievement of students in senior secondary schools in Nigeria and Hawai' $i$ is a pointer to the fact that there is wider acceptance to the difference in achievement of students' based on school type in Nigeria

It was evident from the findings of this research that public-school students outperformed their counterparts in the private school in terms of academic achievement as a result of their computer skills. This finding contradicted the findings of [15] and [3] that students from private school out-performed their counterparts in the public schools. It can be inferred from this result that students irrespective of school type can perform well once the environment is conducive. This result is in tandem with the submission of [9] and [12] that school privatization with the intent to improve educational achievement may only yield short-term gain. The implication is that school type has no effect on academic achievement of students in secondary schools in Ogun State. However, as noted by the findings of this study, students from the public secondary schools in Ogun State outperformed their counterpart from the private schools. This could be as a result of recruitment of qualified teachers by private school proprietors and insufficient funding to pay qualified ones. Another factor could be non-conducive environment in terms of teaching infrastructures and ICT facilities provision.

\section{CONCLUSION}

The findings of this study revealed that there is positive and significant relationship between secondary school students' computer skills and their academic achievement. In addition, the study also established the fact that there is a significant difference in the achievement of secondary school biology students based on school type. The students computer skills resulted in high level of achievement in Biology. It was evident from the findings of this research that public-school biology students outperformed their counterparts in the private school in terms of academic achievement. The implication, therefore, is that the provision of and accessibility as well as the use of computer facilities in the teaching and learning of biology can engender greater students' achievement in the subject.

\subsection{Recommendations}

Based on the findings, discussion and conclusion of this study, the following suggestions were made:

- It is imperative for private school proprietors to ensure only qualified teachers are employed to teach the secondary school students in Ogun State 
- They should also endeavor to provide conducive environment for their students in terms of infrastructures and facilities.

- The Nigerian secondary education curriculum should be reviewed to include computer skills training and computer facilities should be provided for teaching and learning biology in secondary schools in Ogun State of Nigeria.

\section{ACKNOWLEDGEMENT}

The authors acknowledge with thanks, the contribution of all the experts and researchers whose work has been consulted and cited in the development of this study.

\section{REFERENCES}

[1] Adebowale, O.F. Adewale, I.A. and Oyeniran, F.M 2010.Computer interest, approval and confidence of secondary school students in three selected local governments of Lagos State (Nigeria): Implications for global computerization International Journal of Education and Development using Information and Communication Technology 6 (1), 40-52.

[2] Adesehinwa, A. and Aremu, O 2010 The relationship among predictors of child, family, school, society and the government and academic achievement of senior secondary school students in Ibadan, Nigeria. Procedia Social and Behavioral Sciences 5, 842-849.

[3] Afolabi, A. O. 2007. Comparison of private and public schools product's performance in Mathematics and English language from educational technology perspective Ilorin Journal of education 24, 60-64

[4] Akinbobola, A. O and Afolabi, F 2010 Analysis of Science Process Skills in West African Senior Secondary School Certificate Physics Practical Examinations in Nigeria American-Eurasian Journal of Scientific Research 5 (4): 234-240,

[5] Akinfe, E., Olofinniyi, O. E. and Fashiku C.O. 2012. Teachers' Quality as Correlates of Students Academic Performance in Biology in Senior Secondary Schools of Ondo State, Nigeria Online Journal of Education Research Volume .16: 108-114

[6] Ann, L. 2010. Basic computer Skills Survey (Feb $18,2015)$

[7] Anon, 2013 Opon Imo will save Osun N8.4billion of Textbook procurement cost. Channel Television. (April 12, 2014)

[8] Chaudhari, P. 2013. Computer Assisted Instruction (CAI): Development of instructional strategy for Biology Teaching Educational Confab 2 (1), 106-116

[9] Chritimann, E and Badgett, J. 1999. A comparative analysis of the effect of computer Assisted Instruction on student's achievement in differing science and demographic areas Journal of Computer in Mathematics and Science Teaching. 18. 2: 135-143

[10] Danmole, B.T. 2012. Biology Teachers' View on Practical Work in Senior Secondary Schools of South Western Nigeria Pakistan Journal of Social Sciences 2: $69-75$
[11] Federal Republic of Nigeria 2014 FRN National Policy on Education

[12] Figlio, David N and Stone, Joe A 1997 School Choice and Student Performance: Are Private Schools Really Better? in Institute for Research on Poverty Discussion Paper No. 11 ( April 10, 2015)

[13] Kim, J. S. 2005. The Effects of a Constructivist Teaching Approach on Student Academic Achievement, Self-concept and Learning Strategies Education Research Institute,6. 1: 7-19.

[14] Kpolovie, P. J , Joe, A. I. and Okoto, Tracy 2014 Academic Achievement Prediction: Role of Interest in Learning and Attitude towards School International Journal of Humanities Social Sciences and Education 1.73-100

[15] Mburu, D.N.(2013) Effect of the type of school attended on students academic performance in Kericho and Kipkelion Districts International Journal of Humanity and and social Science 3 (40) $45-56$

[16] Microsoft Encarta, 2009. The Encarta Dictionary. Microsoft (March, 10, 20160.

[17] National Information Technology Development Agency 2007. Human Capacity Building Project (April 5th, 2014)

[18] National Examination Council, (NECO) 2006. National Examination Council Syllabus

[19] National Examination Council, (NECO) 2007. National Examination Council Syllabus

[20] National Examination Council, (NECO) 2008. National Examination Council Syllabus

[21] National Planning Commission, (2007), Nigeria Vision 20:2020 Economic Transformation Blueprint 134.

[22] Nwagbo, C.R and Okoro, A.U 2012, Effect of Interaction Patterns on Achievement in Biology among Secondary School students (Feb 4, 2013) from

[23] Obilor, I. E. 2011. Relationship between self-concept and Mathematics Achievement of Senior Secondary Students in Port Harcourt Proceedings of the 1st International Technology, Education and Environment Conference (c) African Society For Scientific Research 924-934

[24] Ofili, G. O. 2012 Instructional Television Utilization for the Enhancement of Cognitive Learning Skills: Implication for the Challenges in Science Education Journal of Educational and Social Research, 2 (7:) $118-123$

[25] Okpala, p. N (2015) performance of candidates in NECO 2009 June/July Transformational Leadership: a documentation and Giant Strides and Milestones of Professor Promise Nwachukwu Okpala NECO. Ideal Concepts: Lagos. 2015.130-13

[26] Rafiq, H. M. Waqas, T F., Malik, M. S, Saleem, M. and Khan, M A (2013) Parental Involvement and Academic Achievement; A Study on Secondary 
School Students of Lahore, Pakistan International Journal of Humanities and Science, 3.8: 209

[27] Takayama, B. 2008 Academic Achievement Across School Types in Hawaiÿi: Outcomes for Hawaiian and Non-Hawaiian Students in Conventional Public Schools, Western- Focused Charters, and Hawaiian Language and Culture-Based Schools (March 20, 2014)

[28] Tabassum, R. 2004. Effect of Computer Assisted Instruction on the Secondary School student Achievement in Science PhD. Thesis Pakistan Research Repository (Jan. 25, 2011)

[29] Ugodulunwa, C. A and Dadughun, S.I. 2011. An assessment of secondary school student performance in Public examinations (Jan, 15, 2013)

[30] WAEC, 2009. West African Examination Council Syllabus.

[31] WAEC, 2010a West African Examination Council Examiners (Nov/Dec. WASSCE) Chief Examiners' Reports Nigeria

[32] WAEC, 2010b West African Examination Council Examiners (Nov/Dec. WASSCE) Chief Examiners' Reports Sierra Leone
[33] WAEC, 2010c West Africa Examination Council Examiners (Nov/Dec. WASSCE) Chief Examiners' Reports Gambia

[34] WAEC, 2010d West African Examination Council Examiners (Nov/Dec. WASSCE) Chief Examiners' Reports Ghana

[35] Wikipedia (2012) computer skills ideology (Mar, 2014)

[36] Yang Kuei-Feng, Yu Shu, Lin Ming-Sheng and Hsu Chia-Ling 2004 Study of Basic Computer Competence Among Public Health Nurses in Taiwan Journal of Nursing Research 12, (1), 20-32

[37] Yusuf, O. and Afolabi, O. 2010. Effects of Computer Assisted Instruction (CAI) on secondary school students' performance in biology The Turkish Online Journal of Educational Technology,91. 62-72

[38] Yusuf, M. A and Adigun, J. T. 2010 The Influence of School Sex, location and Type on Students' Academic Performance Kamla-Raj 2010 Int J Edu Sci, 2(2): 81-85. 